\title{
Correction to: Recurrent cholera epidemics in Africa: which way forward? A literature review
}

\author{
Abraham Ajayi ${ }^{1}$. Stella I. Smith ${ }^{2}$
}

Published online: 11 March 2019

c) Springer-Verlag GmbH Germany, part of Springer Nature 2019

\section{Correction to: Infection \\ https://doi.org/10.1007/s15010-018-1186-5}

The original version of this article unfortunately contained a mistake. In the introduction, the infectious dose of Vibrio cholerae was written as $103-108$ instead of $10^{3}-10^{8}$ cells.

The original article can be found online at https://doi.org/10.1007/ s15010-018-1186-5.

Stella I. Smith

stellaismith@yahoo.com

1 Department of Microbiology, University of Lagos, Akoka, Lagos, Nigeria

2 Molecular Biology and Biotechnology Department, Nigerian Institute of Medical Research (NIMR), Yaba, Lagos, Nigeria 